\title{
A VIAGEM DE MARIA TERESA HORTA PELO BRASIL ${ }^{36}$
}

\section{MARIA TERESA HORTA'S TRIP THROUGHOUT BRAZIL}

\author{
Ilca Vieira de OLIVEIRA ${ }^{37}$
}

\begin{abstract}
RESUMO: O presente texto apresenta um estudo sobre a viagem nos Poemas do Brasil (2009), de Maria Teresa Horta, ressaltando como o eu-lírico constrói pequenos retratos de mulheres e das belezas naturais quando viaja pela geografia e literatura do Brasil. Os Poemas do Brasil, compostos por essa viajante do século XXI nos lembram os primeiros cronistas do século XVI, que se encantavam com as belezas e as riquezas da terra descoberta, mas revelam a síntese das composições de Pau-brasil, do poeta modernista Oswald de Andrade. A viagem representada nos poemas começa com a saída da poetisa de Portugal e se desdobra em outras viagens que são representadas pelo trajeto feito entre São Paulo e Rio de Janeiro e as incursões pela literatura brasileira.
\end{abstract}

PALAVRAS-CHAVE: Poesia portuguesa contemporânea; Imagens do Brasil; Viagens e paisagens.

ABSTRACT: This present text presents a study on the trip of Poemas do Brasil (2009), by Maria Teresa Horta, emphasizing the way the lyric I builds small lyrical portraits of women and the natural beauty while traveling through Brazilian geography and literature. Poemas do Brasil, comprised by this twenty-first century traveler reminds us of the first chroniclers of the sixteenth century, who were enchanted with the beauties and riches of the discovered land, but reveal the composition synthesis of Pau-brasil, by the modernist poet Oswald de Andrade. The trip represented in the poems begins with the exPortuguese poet and unfolds into other trips that are represented by the itinerary between São Paulo and Rio de Janeiro and the incursions into Brazilian literature.

KEYWORDS: Portuguese contemporary poetry; Images of Brazil; Trips and landscapes.

\footnotetext{
${ }^{36} \mathrm{O}$ presente texto é resultado da pesquisa desenvolvida no projeto "Cidades de Minas na poesia brasileira do século XX", financiado pelo CNPq e com Bolsa BIPDT/FAPEMIG.

${ }^{37}$ Departamento de Comunicação e Letras. Programa de Pós-Graduação (Mestrado) em Letras (Estudos Literários) - Centro de Ciências Humanas - Universidade Estadual de Montes Claros (UNIMONTES) CEP 39401-089 - Montes Claros - MG - Brasil - ilca.vieira@pq.cnpa.br / ilcavieiradeoliveira@yhaoo.com.br
} 


\section{BRASIL}

Tão secreto

tão pujante

no excesso onde excedia

tudo

onde adivinhava

o que ainda eu não via

(Maria Teresa Horta, p.17).

"Brasil" é o poema que abre o livro Poemas do Brasil (2009), de Maria Teresa Horta, e marca o início de uma experiência poética motivada pela viagem que essa escritora portuguesa realizou pelo Brasil em 2007. Tem-se um eu que, diante do desconhecido, procura descobrir o que há de "Tão secreto" nesse País que é "tão pujante/no excesso onde excedia". O que se tem é um sujeito que ainda não conhece esse lugar para onde irá nessa viagem, mas que já imaginava o que encontraria em seu trajeto, principalmente quando ressalta nos versos: "adivinhava/o que ainda eu não via". Com esses versos, podemos apontar que o eu sugere para o seu leitor que ele já conhecia esse espaço geográfico através do olhar do outro; nota-se que a imagem do Brasil já faz parte do imaginário desse sujeito que deseja a viagem, provavelmente tenha surgido a partir da visão construídas pelos "viajantes" do passado e do presente, que apaixonados pelo exótico saíram de suas nações para experimentar novas sensações e descobrirem novas paisagens.

A imagem dessa terra além-mar também pode ter sido apreendida a partir da biblioteca com "os seus livros, os atlas, os romances, os poemas" que contribuem para que a poeta-viajante escolha o seu destino. Michel Onfray (2009), em seu texto Teoria da viagem: poética da geografia, afirma que todas "as seções de uma biblioteca conduzem ao bom lugar" e, que antes do viajante se deslocar fisicamente do seu espaço de enraizamento ele já realizou inúmeras viagens através do texto escrito. E, ao destacar a importância do papel, faz o seguinte comentário:

O papel instrui as emoções, ativa as sensações e amplia a possibilidade próxima de percepções preparadas. O corpo se inicia nas experiências vindouras a partir de informações generalizadas. Toda documentação alimenta a iconografia mental de cada um. A riqueza 
de uma viagem requer, a montante, a densidade de uma preparação assim como experiências espirituais convidam a alma à abertura, ao acolhimento de uma verdade capaz de infundir. A leitura age como rito iniciático, revela uma mística pagã. $O$ aumento do desejo desemboca a seguir num prazer refinado, elegante e singular. (ONFRY, 2009, p. 25-26).

O Brasil surge como um "enigma" para essa viajante que deixa o seu país para mergulhar num mundo até então desconhecido, mas que ela desejava descobrir. O "ver" e o "ser visto" serão explorados em vários poemas como uma construção metafórica, pois é no momento em que a poeta se desloca de seu país de origem e se vê diante do outro que ocorrem os conflitos interiores, desencadeando várias reflexões sobre a identidade. O livro recria, através de poemas, a viagem de Maria Teresa Horta pelo Brasil, em 2007. Essa "poesia cantante" cria a figura de uma escritora que irá tecer o seu destino "quando se inventa" e, também, o destino de outras mulheres que vão: "Renascendo com vagares/à sombra da própria seda/na chama rubra da renda" (HORTA, 2009, p. 53), das mãos dessa maga. Com a viagem, que ocorre em setembro, a poeta consegue recolher a matéria-prima para os seus poemas que tratam de temas relevantes, entre eles o ofício de ser escritora, a reflexão sobre a poesia e o fazer literário e, também, o papel da mulher na literatura, principalmente nos retratos que cria das amigas e das escritoras brasileiras.

Não será possível dedicarmos uma leitura mais apurada de todos os poemas que evocam as imagens das "mulheres brasileiras", mas na última parte deste estudo será colocado em discussão o "retrato" de Cecília Meireles. Este retrato ganha destaque, aqui, não só pelo fato de Maria Teresa Horta estabelecer um diálogo com a poesia da escritora brasileira e por demonstrar admiração por seus poemas e sua vida, mas porque nos Poemas do Brasil, a viagem constitui a matéria primordial nessa poesia, tema que também é recorrente na poética de Cecília.

\section{O desejo da viagem: o corpo no espaço do "entremeio"}

Foi assim que, bem devagar,

O País das Maravilhas foi urdido, Um episódio vindo a outro se ligar -

E agora a história está pronta,

Desvie o barco, comandante! Para casa!

O sol declina, já vai se retirar. 
(Lewis Carrol, 2009, p.11).

O desejo da viagem inicia bem antes do sujeito deslocar-se. E, realizar uma viagem requer certa preparação. O projeto da viagem que será realizada se define pela "vontade", "desejo" e "leitura", mas é quando a poeta deixa para trás Lisboa, como os seus antepassados que se lançaram ao mar em busca desse "País das Maravilhas", que ela inicia de vez a sua viagem.

E ver com os seus próprios olhos e sentir todas as emoções de encontrar essa pátria com a qual partilhava a mesma língua era uma experiência única que a poeta irá externar em vários poemas. Nesse primeiro poema do livro e nos outros três que vão sucedê-lo, que são "Espelho", "Voo" e "Como fazer?", são composições que tratam da travessia do Atlântico e dos medos e expectativas que fizeram parte da viagem.

No poema "Espelho" a poeta revela o início da viagem para um espaço desconhecido e "mágico", no voo real, retrata o seu deslocamento de Lisboa para o Brasil, e no voo imaginário traz o seu "vagar" pelo mundo das incertezas e das dúvidas. E, ao se colocar diante do espelho se vê como a própria personagem "Alice" das histórias de Alice no País das Maravilhas e Através do espelho e o que Alice encontrou por lá, de Lewis Carroll. A "poeta-menina" mergulha no mundo da fantasia e do mágico e, também passará por transformações ao longo de todo o seu trajeto, no "vago das nuvens" tem-se um eu que explicita os seus medos e dúvidas, como se segue no poema:

\author{
"Espelho" \\ Olho com reflexos \\ de espelho \\ trazendo Alice comigo \\ Depressa no seu vagar \\ mais lenta \\ no meu sorriso \\ Vendo-me a oscilar \\ na desmesura \\ do vidro
}

(HORTA, 2009, p.18). 
Nessa viagem para esse país "tão pujante", com os "seus excessos" e os seus enigmas, ou seja, para o "País das maravilhas", o eu-lírico não deixa de explicitar os questionamentos que estão presentes nas narrativas de Lewis Carroll. Nesse sentido, é possível afirmar que se trata de uma viagem para "o interior de si mesmo" em que ocorre o crescimento e o aprendizado. É importante observar que a poeta revela os seus medos e as expectativas diante do Brasil no início da viagem, mas o que ocorre, ao longo de seu itinerário, é que esses sentimentos vão se desfazendo para dar lugar a uma poética marcada pela "epifania".

No poema "Voo" não registra simplesmente a face externa que os seus olhos enxergam, mas expõe as suas angústias e medo do encontro com o outro e, para amenizar a "tristeza" e o "desacerto", leva consigo "a caneta e o poema" e "A amiga/do lado certo/a defender o abrigo". Vejamos todo o poema a seguir:

"Voo"
\[ \text { À Vanda Anastácio } \]
À partida de Lisboa
deixei a minha amargura
atada à perna da mesa
E fui voando comigo
o livro aberto no colo
a caneta e o poema
A amiga
do lado certo
a defender o abrigo
Abandonada
A tristeza
E o desacerto inimigo

(HORTA, 2009, p. 19).

O poema expõe o primeiro momento da viagem que é o "entremeio", que, de acordo com Michel Onfray, "tem a ver com a lógica espacial”, ou seja, o viajante não está no lugar deixado e ainda não se encontra no lugar desejado. E o corpo, nesse espaço do entremeio, na concepção de Onfray (2009, p. 35-36), fica:

Flutuando, vagamente ligado a duas margens, num estado de ausência de peso espacial e temporal, cultural e social, o viajante penetra no entremeio como se abordasse as costas de uma ilha singular. Cada vez 
mais longe do seu domicílio, cada vez menos distante da sua destinação, circulando numa zona branca, neutra, o indivíduo escala ficticiamente uma encosta ascendente, atinge um ponto zenital, para depois iniciar a descida.

Os versos do poema explicitam um corpo que se encontra no entremeio e experimenta a "extraterritorialidade", e é nessa geografia particular, destituída da "rigidez social" e das "regras coletivas", que o eu poético inicia a sua viagem reflexiva. Esse eu, que se olha no espelho e faz os seus questionamentos, se revela com mais intensidade no poema "Como fazer?", em que surge o medo de deixar o outro e de perdê-lo durante a ausência, levando a poeta a dizer:

\author{
"Como fazer?" \\ Não sei como passar \\ tantos dias \\ sem te ver \\ meu amor como fazer? \\ Tanta distância sofrida \\ tanto mar no desfazer \\ tanto sentir a partida \\ meu amor como fazer? \\ Se viajar \\ nos teus braços \\ tem mais vertigem o prazer \\ meu amor como fazer? \\ E se a saudade crescida \\ de tanto me maltratar \\ se for tornando infinita \\ e o perigo de te perder?
}

(HORTA, 2009, p. 20).

O próprio sentido da viagem que se destaca, nos poemas analisados anteriormente, como trajeto real da poeta que se desloca de Portugal para o Brasil e como um mergulho no mundo interior em busca de identidade, também ganhará outro sentido no poema "Como fazer?". A palavra "viajar" não é mais exposta no sentido de deslocamento geográfico e imaginário, mas sugere um sentido erótico, de alguém que 
deixa o seu amor e tem medo de perdê-lo. O poema é todo construído com uma linguagem que sugere a sensualidade e o erotismo, desencadeando uma reflexão e um diálogo com o outro, que se encontra ausente. $\mathrm{O}$ eu exterioriza a saudade, os medos e as dúvidas nos versos das duas últimas estrofes, pois o que mais atormenta a viajante é o "perigo" de perder esse outro. O grande medo do viajante é não conseguir retornar à sua terra de origem, ou seja, o "perigo de extravio definitivo da alma". Diante das possibilidades de leituras, o medo exposto também pode ser lido como um sentimento destinado ao seu próprio país de origem, Portugal.

A identificação entre o espaço externo do país exótico (Brasil) e a interioridade do eu-lírico irá se destacar em vários poemas, pois a poeta não irá revelar somente aquilo que os seus olhos viram, mas procura as sensações e as impressões que essa paisagem deixou em sua própria "alma”. É nesse material poético que surge um sujeito que inscreve o desejo e a sedução como encontramos nos versos do poema "Nó e Laço", que explicita: "Onde a natureza/em ti/ dá nó e laço/Para vir atar em mim/o que não faço". No poema seguinte, que recebe o nome de "Desejo", o eu se expõe da seguinte maneira: "Avanço a ponta/dos dedos/na mata da tua nuca/Onde meu beijo/se perde/e na entrega desnuda" (HORTA, 2009, p. 89). O corpo do país se transforma em corpo amante, o uso da palavra "mata" que se refere aos cabelos do amante no poema pode também significar a flora brasileira. $O$ texto expõe uma linguagem sensorial, os dedos percorrem o corpo do outro como alguém que decifra "mapas e cartas/com bússola e astrolábio", e que se perde na entrega livre e "desnuda". E a viajante tem medo de se perder nesse país encantado e/ou mesmo ser seduzida pelas belezas e, quem sabe, "pelos cantos dos seus pássaros", jamais conseguindo retornar de sua viagem para os braços de sua terra de origem.

O poema "Amigas brasileiras", que fecha Poemas do Brasil, já nos expõe que os medos e as dúvidas não são mais sentimentos que incomodavam a viajante, já que o medo de se perder no corpo desse país "tão exuberante" fora superado, pois a poeta descobre os laços e as amizades eternas no convívio com as mulheres e amigas desse outro espaço geográfico. Esse poema busca traduzir em versos os sentimentos e as emoções que foram experimentados durante a viagem. Nos fios desse bordado poético, o sujeito lírico assume o ofício de fazer, desfazer e refazer o tecido literário e urdir as amizades. No fragmento do poema abaixo, veja-se essa partilha se realiza: 


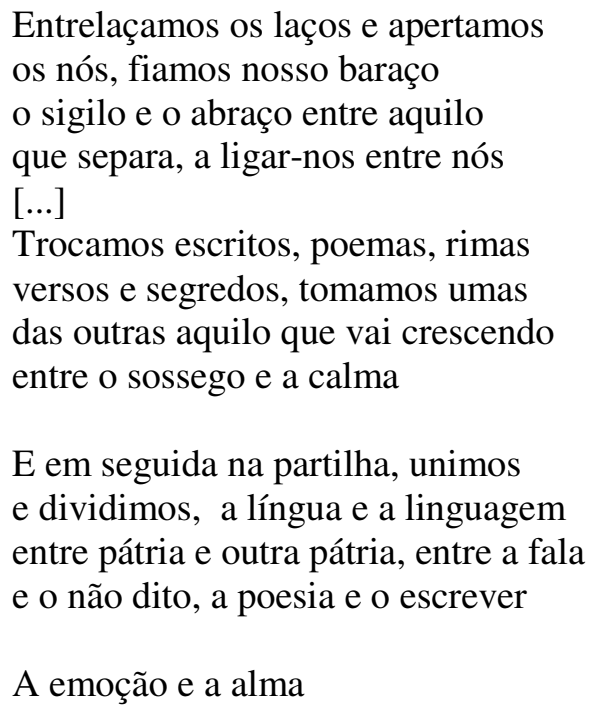

(HORTA, 2009, p. 113).

A metáfora do espelho se desdobrará em outros poemas e o "olhar" se configura a partir de um eu que busca conhecer a "paisagem", os lugares mais recônditos e, especificamente, as mulheres desse país mágico e tão secreto. A portuguesa também quer conhecer aqueles que olham para a sua "poesia", e isso pode ser percebido em vários poemas que serão dedicados aos estudiosos de sua produção poética no Brasil, que são Ana Maria Domingues, Conceição Flores, Jorge L. Marques, Gilda Santos etc. O poema "Olhar", por exemplo, reapresenta-nos como Maria Teresa Horta se coloca em relação à "amizade" e aos "olhares dos críticos" e, poeticamente, surge uma visão reflexiva que ganha destaque em todos os versos.

\section{O viajante, a contemplação e o registro poético}

Vou pelas sebes do sonho costurando o meu silêncio fio de nó e primavera

Pesponto, bordo, porfio na orla mansa da ria a invenção mais desperta

(HORTA, 2009, p. 58). 
A segunda parte do livro, "São Paulo", é composta de vinte e três poemas. O título revela o que o leitor vai encontrar: uma poética da viagem que, por sua vez, prioriza a paisagem e os elementos culturais de São Paulo. O poema "Chegada" abre essa série de composições que tratam do período em que Maria Teresa Horta esteve em São Paulo em 2007, e representa a experiência de alguém que chega ao Brasil e inicia o seu itinerário de descoberta e conflitos interiores. Na primeira estrofe do poema, "Chego e torno no passo/vou até meus anos/antes", já temos um eu que, antes de demonstrar o que sente ao encontrar com esse outro, já traz uma reflexão sobre a viagem no sentido de retorno ao passado e "busca de identidade", ou seja, de alguém que explicita os seus contrastes interiores em "chego e torno" e, também um medo de se perder nos braços desse outro, como irá demonstrar em vários poemas, por exemplo, em "Perdimento", "Desacerto" e "Mata Atlântica".

Esses versos, da primeira estrofe de "Chegada", também sugerem ao leitor a possibilidade de fazer uma leitura mais profunda, pois existe um eu que direciona o seu olhar para "o passado", mas esse tempo não pode ser lido simplesmente como um retorno à infância, ou mesmo a um sentimento nostálgico; mas sugere um passado histórico, ou seja, a chegada dos primeiros colonizadores portugueses ao Brasil, pois existe um eu-lírico que se identifica com o espaço geográfico, e que, a todo instante, quando olha para o país onde está irá encontrar "parte de uma outra pátria”. Nas outras estrofes do poema o eu-lírico deixa explícito que a chegada foi de "entrega e alvoroço", e que trazia de Portugal "a festa/na sua haste/Dois livros/o cravo/o gosto/Da liberdade o engaste/o rumor/o riso/o rosto" (HORTA, 2009, p. 24).

Os poemas da série "São Paulo" encenam a experiência da viagem e o momento em que o viajante experimenta as sensações e penetra na essência da coisa. E a poeta precisa criar algumas referências para organizar o conjunto da viagem, que mais tarde irá formar uma "geografia sentimental". Para isso, essa viajante pode utilizar várias técnicas, tais como a "fotografia, a pintura, uma anotação ou um cartão-postal", mas, segundo Michel Onfray:

Somente a experiência escrita permite dar conta da totalidade dos sentidos. Os outros suportes são relativamente pobres: a aquarela, o desenho, a foto captam o real numa de suas modalidades - a cor, a linha, o traço, o desenho, a imagem -, nunca de forma integral. [...] Já o poema, como quintessência do texto, mas também a prosa, podem 
captar e restituir o cheiro de jasmim de um jardim do Oriente. [...] Somente o verbo circunscreve os cinco sentidos, e mais. $\mathrm{O}$ trajeto conduz das coisas às palavras, da vida ao texto, da viagem ao verbo, de si a si. (ONFRAY, 2009, p. 100).

Nessa viagem pelo Brasil, existe um eu que se identifica com o espaço e constrói várias imagens das paisagens naturais que se entrelaçam com as imagens femininas e com a própria poesia. Os Poemas do Brasil, compostos por essa viajante do século XXI nos lembram os primeiros cronistas do século XVI, que se encantavam com as belezas e as riquezas da terra descoberta, mas revelam a síntese das composições de Pau-brasil, de Oswald de Andrade. O poema "Pau-brasil" faz parte da série de poemas que são nomeados como "Serra do Mar" e, que já traz como título o livro de poemas desse escritor brasileiro, confirmando a técnica que a viajante utiliza em sua viagem ${ }^{38}$.

As anotações são feitas, mas o poético exige um certo refinamento, e o que o leitor irá encontrar é uma poesia que explora ao máximo a imagem do Brasil com uma linguagem musical, sugestiva e marcada pela sonoridade e pela sensualidade. A poeta portuguesa contemporânea expõe uma visão diferente do "colonizador" do passado e do turista do presente que "não aprofunda" na cultura do outro. Existe não só o diálogo com o texto de Oswald de Andrade, mas também sobressai uma reflexão sobre o "paubrasil", que de matéria prima - explorada e levada pelos colonizadores portugueses passa a ter sentidos diversos, por exemplo, o erótico e o de representação do poder, como se pode ver nas estrofes seguintes:

\author{
Pau-de-lagoa \\ noturna \\ pau de colher prazer
}

\footnotetext{
${ }^{38}$ Ana Maria Domingues, no "Prefácio" que fez para o livro, relata o processo de elaboração dos poemas sobre o Brasil, e também relata o período em que a poeta Maria Teresa Horta esteve em sua companhia. O texto do prefácio, citado a seguir, ajudará o leitor a compreender melhor as técnicas que foram usadas pela escritora durante a viagem: "Mas voltemos àquele primeiro encontro, em setembro de 2007. Pudemos participar do congresso juntas e eu tive a grata surpresa de - bastante atemorizada - ter a própria autora, sobre quem mais uma vez falava, como ouvinte de minhas palavras. Além disso, convivemos bastante naqueles dias, e a todo momento eu via que Maria Teresa Horta abria seu caderno e tomava notas. Às vezes me perguntava o nome de alguma planta, de alguma árvore, de alguma flor, e anotava tudo em seu caderno. Confesso que minha curiosidade de leitora voraz de suas palavras ficava bastante atiçada... [...] Algum tempo depois de voltar a Portugal, Teresa anunciou-me que estava preparando um livro intitulado Poemas do Brasil, com textos que nasceram naqueles dias. Então era esse o motivo daquelas anotações! E logo eu tive o privilégio de acompanhar, mesmo a distância, o processo de composição de boa parte da obra, recebendo textos anexados a e-mails e finalmente conhecendo na íntegra o livro que agora os leitores têm na mãos." (DOMINGUES apud HORTA, 2009, p. 13).
} 
Pau-de-lacre

pau-de-águia

de praga e seu poder

(HORTA, 2009, p. 63).

A poeta não se porta como uma "turista" estrangeira que fotografa as belezas da terra e que deseja encontrar as melhores paisagens e visitar todos os lugares, principalmente para comprar souvenir, mas como uma "viajante" que se preocupa em conhecer os lugares com as suas histórias e as suas riquezas literárias. É importante destacarmos, aqui, que o "turista" e o "viajante" apresentam atitudes diferentes. Sobre essa diferença entre os dois, veja-se o comentário de Michel Ofray:

Viajar supõe menos o espírito missionário, nacionalista, eurocêntrico e estreito, do que a vontade etnológica, cosmopolita, descentrada e aberta. O turista compara, o viajante separa. $\mathrm{O}$ primeiro permanece à porta da civilização, toca de leve uma cultura e se contenta em perceber sua espuma, em apreender seus epifenômenos, de longe, como espectador engajado, militante de seu próprio enraizamento; o segundo procura entrar num mundo desconhecido, sem intenções prévias, como espectador desengajado, buscando nem rir nem chorar, nem julgar nem condenar, nem absolver nem lançar anátemas, pegar pelo interior, que é compreender, segundo a etimologia. $\mathrm{O}$ comparatista designa sempre o turista, o anatomista indica o viajante. (ONFRAY, 2009, p. 68-69).

A distinção entre o turista e o viajante, exposta acima, nos ajuda a interpretar os Poemas do Brasil, como já afirmei antes, quando teci considerações sobre poemas anteriores, o que o eu-lírico evoca em todo esse tecido poético é a experiência de um viajante que irá "compreender" a cultura do outro e considerar as suas diferenças. Essa distinção entre o turista e o viajante, que é discorrida por Michel Onfray, remete-nos à crônica "Roma, turistas e viajantes" (1953), de Cecília Meireles, que considera:

Grande é a diferença entre o turista e o viajante. O primeiro é uma criatura feliz, que parte por este mundo com a sua máquina fotográfica a tiracolo, o guia no bolso, um sucinto vocabulário entre os dentes: seu destino é caminhar pela superfície das coisas, como do mundo, com a curiosidade suficiente para passar de um ponto a outro, olhando o que lhe apontam, comprando o que lhe agrada, expedindo muitos postais, tudo com uma agradável fluidez, sem apego nem compromisso, uma vez que já sabe, por experiência, que há sempre uma paisagem detrás da outra, e o dia seguinte lhe dará tantas surpresas quanto a véspera. 
O viajante é criatura menos feliz, de movimentos vagarosos, todo enredado em afetos, querendo morar em cada coisa, descer à origem de tudo, amar loucamente cada aspecto do caminho, desde as pedras mais toscas às mais sublimadas almas do passado, do presente e até do futuro - um futuro que ele nem conhecerá. (MEIRELES, 1999, p. 101).

Maria Teresa Horta é a viajante que atravessa o Atlântico, em busca deste país desconhecido, mas não passa pelo Brasil como uma "turista apressada" que reproduz o mundo com sua "máquina fotográfica", construindo uma visão superficial das coisas, mas como alguém que "se deixa ficar em cada coisa" e que apreende os pormenores da história do lugar visitado. É nos rastos da letra que o sujeito poético inscreve o seu canto lírico com toda a intensidade de que mergulha nessa nova geografia e descobre os seus pormenores. Existe uma identificação com a paisagem que se enxerga e a interioridade do eu-lírico. É o que podemos ver no poema:

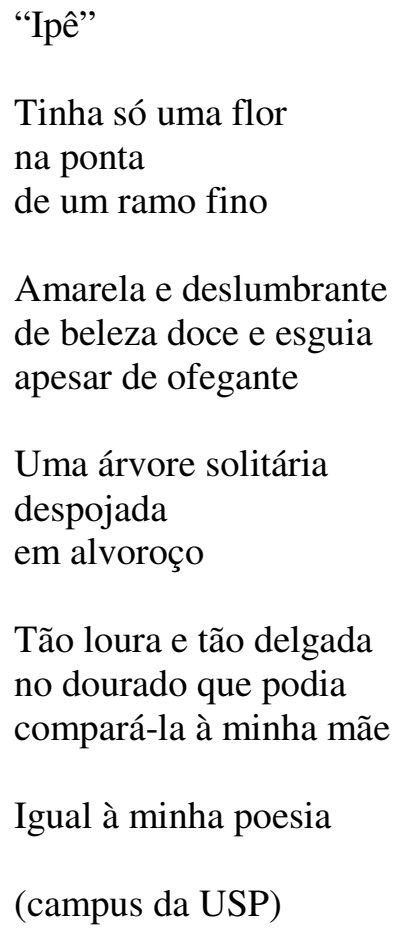

Tão loura e tão delgada no dourado que podia compará-la à minha mãe

Igual à minha poesia

(campus da USP)

(HORTA, 2009, p. 37).

O poema é construído com a matéria-prima do lugar em que se encontra a escritora. O ipê e sua flor de "beleza doce e esguia" se transformam em objeto de contemplação e matéria poética. Entre os dedos dessa feiticeira e rendeira surge a imagem de uma "árvore solitária/despojada/em alvoroço" que possui uma "só flor" que 
é nomeada com intensidade a partir do advérbio "tão", pois não se tem uma flor qualquer, mas é uma flor "Tão loura”, "Tão delgada", com um "dourado" que é, antes de tudo, "Amarela e deslumbrante". A flor metaforiza a transitoriedade e a brevidade da vida e, quando comparada à figura materna e à poesia, traz em si a subjetividade e o lirismo. Nesse bordado, a árvore e a flor se entrelaçam na poesia que é tão efêmera como a própria "flor" do ipê amarelo.

No início do livro, o Brasil é representado como um espaço incerto e desconhecido para a poeta-viajante, principalmente nos poemas que antecedem a sua chegada a São Paulo; mas à medida em que ocorre o percurso da viajante, novas imagens da terra vão sendo construídas. O espaço geográfico é retratado por um sujeito lírico que tem consciência da impossibilidade de representar o que se enxerga, pois o que se consegue inventar é um "mundo de sonho" e imagético, captado a partir da sua experiência sensorial de escutar o canto dos pássaros da terra encantada. A viagem possibilita ao viajante "verificar por si mesmo o quanto o país visitado corresponde à ideia que se faz dele" (ONFRAY, 2009, p. 57), pois é quando o sujeito se desloca para o lugar desejado que ele é capaz de "compreender" melhor o outro; essa capacidade de lidar com o outro e com as suas diferenças é importante para que o viajante se desfaça de ideias preconcebidas, principalmente aquelas que lhes foram apresentadas através de visões reduzidas.

E, para conhecer o outro, a poeta assume a identidade de seres mágicos que povoam o mundo da fantasia e do maravilhoso, como podemos ver nos versos: "E de mim própria confesso/Sou poetisa e sou maga/Sou filha da profecia", do poema "Rastro". Mesmo sendo "maga", bruxa e feiticeira da palavra, a tecedeira nem sempre consegue "desatar" os nós e os laços, ou seja, compreender todos os sentimentos das mulheres amigas, das personagens da literatura brasileira, das pintoras e das escritoras, principalmente quando se quer conhecer os seus enigmas. Vejamos o poema:

\footnotetext{
"Veio a veio"

Vou juntando

veio a veio

os estames das suas vidas

De Capitu a revolta

a pintura de Anita
} 
os versos de Auta e Gilka

Com a bruma rigorosa

a consumir-lhes as veias

e a paixão envenenada

No assombro das ideias

(HORTA, 2009, p. 46).

A poeta não é uma "turista" que pretende fotografar a paisagem e as belezas da terra com avidez; nem uma "colonizadora" que quer se apropriar das riquezas brasileiras; mas se coloca como uma verdadeira "viajante" que deseja conhecer a cultura do país e ficar em cada coisa.

Se durante o período de colonização os portugueses exploraram as riquezas brasileiras, principalmente o pau-brasil, a autora não deixa de fazer uma reflexão sobre a história do Brasil, como podemos encontrar nas duas últimas estrofes do poema "Jardim Botânico", da última série do livro que recebe o nome de "Rio de Janeiro". A primeira estrofe traz uma descrição do espaço do jardim da seguinte maneira: "Ali há um sossego esvoaçante/além, está um recanto/a paz sombria"; na segunda estrofe: "Galopando o eterno tempo fora/A memória! A memória!/entre o ontem e o hoje feitos da História". Já em outro poema, "Palmeiras imperiais", a sua visão é ainda mais crítica quando direciona o olhar para a colonização portuguesa no Brasil:

\author{
"Palmeiras imperiais" \\ As áleas ou as aléias \\ das palmeiras imperiais \\ Na geometria do tempo \\ na construção dos umbrais \\ Da memória perseguida \\ da História com gente insana \\ Entre a conquista e a perda \\ se a recordação deixar \\ De um Portugal largado \\ do outro lado do mar
}

(HORTA, 2009, p. 94). 
Outros poemas do livro também vão explorar essa temática que trata do tempo, da memória e da história, com um sujeito lírico que, ao se deparar com a "paisagem" e os "monumentos históricos" do Brasil, faz uma reflexão sobre os feitos dos portugueses durante o período da colonização. E tal visão se torna bem mais crítica em relação à colonização que aqui se estabeleceu nos poemas "Forte de S. João de Bertioga" e "PauBrasil", da série "Serra do Mar"; e nos poemas "Enlaçamento", "Real Gabinete de Leitura", "Praça Alexandre Herculano" e "Portuguesa", da série "Rio de Janeiro".

A seguir será feita algumas considerações sobre o retrato que Maria Teresa Horta esboça de Cecília Meireles, que também traz como marca de sua escrita uma poética da viagem.

\title{
3. O retrato da "pastora de nuvens"
}

Como destacamos anteriormente, as poetisas, as investigadoras e as amigas são lembradas nessa "poesia cantante" de Maria Teresa Horta, e a poeta Cecília Meireles aparece em alguns poemas, tais como: "Balada" e "Viagens de Amigas", recebendo um tratamento especial no poema que é intitulado "Cecília Meireles". Podemos afirmar que a viagem da escritora portuguesa pelo Brasil também se configura como uma viagem literária, já que ela deixa claro que deseja seguir o rasto das escritoras brasileiras e "da história literária". No poema "Poetisas brasileiras", o eu-lírico identifica-se com o outro (a outra) e procura conhecer o seu "mundo interior", penetrar nos vãos impenetráveis de suas palavras, e vai atrás do rasto da criação de cada uma. Vejamos a última estrofe do poema:

\author{
No rasto da criação \\ sigo atrás das suas vidas \\ quero saber dos seus cheiros \\ E das suas neblinas
}

(HORTA, 2009, p. 85).

Este fragmento ajuda-nos a compreender melhor a viagem de Maria Teresa Horta e o seu encanto pelas "poetisas brasileiras", dedicando alguns poemas para estas mulheres e apreendendo temas que estarão presentes em suas composições, principalmente Cecília Meireles, que receberá destaque em Poemas do Brasil. Vale 
considerar que a própria temática da viagem, que é explorada em toda a criação literária de Cecília, será retomada de maneira explícita no livro de Maria Teresa Horta.

O poema "Viagem de amigas", da série "Serra do Mar", que é dedicado a Marise Vaz Bridi, trata da viagem no sentido real e imaginário. O eu-lírico situa o leitor no instante em que a poeta visita os lugares com as amigas e alinhava os laços de amizade, ao mesmo tempo em que cria um ambiente marcado pela subjetividade. O tempo é tomado no sentido de algo passageiro e o eu-lírico viajante expõe que é necessário aproveitar cada instante da viagem, já que se tem data para retornar, conforme se lê nos versos da primeira estrofe do poema: "Nós corremos contra/ o tempo/voávamos por entre as nuvens", parece que existe uma angústia por um eu que não consegue deter a passagem das horas. E o sujeito precisa aproveitar cada momento da viagem, logo em seguida, na segunda estrofe descreve alguns fatos, tais como:

\author{
Bebemos água de coco \\ ouvimos Elis Regina \\ fechadas no carro \\ Primeiro paramos olhando \\ mais além \\ alinhavámos \\ Ali calámos sorrindo \\ curiosas e distraídas \\ logo depois confessamos \\ Subimos escadas \\ de pedra \\ fitámos o horizonte
}

(HORTA, 2009, p. 77).

O sujeito se desprende de acontecimentos da realidade, se insere no mundo da subjetividade, principalmente quando se refere às ações que sugerem o fugidio, o vago e o aéreo, por exemplo, o olhar "mais além", o estar distraído, "fitámos o horizonte", "passeámos ao luar/tentando/encontrar o sono" e "esquecemos a eternidade". O tempo é explorado também no sentido de "entrelaçamento", ou seja, a confluência de vários tempos, passado, presente e futuro. No presente, ocorre uma construção da viagem no sentido real, pois o sujeito tenta recompor os passeios, trata do futuro ao dizer "Fizemos planos/simples/vendo crescer a amizade" e destece os fios da memória e da história quando discute o fazer literário, nos versos: 


\section{Invocámos as escritoras \\ na textura do papel \\ da história da literatura \\ Os poemas de Cecília \\ A chama de Florbela \\ Os romances de Virgínia}

(HORTA, 2009, p. 77).

Na produção de Cecília Meireles encontramos as viagens reais e imaginárias, os deslocamentos reais descritos nas várias Crônicas de viagens em que a poeta descreve as várias viagens que fez pelo Brasil e por vários países, especialmente Portugal. Em sua produção poética também encontramos vários poemas que tratam da viagem em vários sentidos. Os lugares visitados e percorridos em viagens reais foram representados em livros escritos por Cecília entre 1952 a 1960. Para Miguel Sanchez Neto (2001), esses lugares aparecerem como "retratos de uma grande pátria transcendente, que é a Índia, Minas da Inconfidência, Itália, Portugal, Jerusalém, Roma etc. É a pátria que supera as fronteiras espaço-temporais deste apertado país dos vivos e busca a eternidade experimentada nas palavras aéreas" (SANCHEZ NETO, 2001, p. liv). Assim, quando viaja por esses lugares a poeta "se reconhece inúmera". Nos livros Metal rosicler (1960) e Solombra (1963), a escritora dará continuidade à temática da viagem por países que não estão no mapa, ou especificamente "os fluidos países por onde passeia" a "pastora de nuvens". A figura de Cecília também surge das indagações elaboradas no poema "Balada", do citado livro de Maria Teresa Horta (2009, p.49):

Onde está o embuçado

Onde está

o caçador

o salteador da estrada

a fera

louca de dor?

Onde está o anjo

alado

a feiticeira perdida?

A Clarice

A Hilda

A tristeza de Cecília? 
O texto é todo construído a partir de indagações, e todas as suas estrofes se fecham com interrogações que também não são respondidas. Existe uma voz que pergunta, mas não encontra respostas, e a repetição das perguntas nos versos vai aumentando cada vez mais o tom de silêncios e vazios. A poeta portuguesa segue atrás das vidas das escritoras brasileiras citadas no texto, mas só irá encontrar seres mortos e os seus rastos nos escritos, ou seja, todas são "sombras". Os elementos mórbidos e sombrios também são evocados quando o retrato de Cecília é esboçado no poema “Cecília Meireles". Neste, a viagem para o desconhecido mundo dos mortos aparece quando o eu-lírico constrói uma espaço arruinado e decadente da casa e do jardim:

Vi o vulto de Cecília
num sussurro
ao pé da escada
A sua pele morena
a confundir-se
com a sombra
Da árvore em declínio
onde ela estava
encostada
E o seu olhar de
lustro
perdido no horizonte?
E os pés na relva alta
do jardim arruinado
na desordem decadente?
Talvez tivesse consigo
um caderno de poemas
apertado na mão esguia
E encostada ao portão
tocando a pedra fria
tentando em vão inventá-la

(HORTA, 2009, p. 96).

O eu-lírico, ao criar uma imagem da poeta brasileira, conduz o leitor para a poesia de Cecília Meireles, principalmente quando constrói um espaço fantasmático. A imagem não aparece com nitidez, pois o que se tem é um vulto do passado que se 
confunde com a sombra. O elemento sombrio que antecede as trevas é explorado com intensidade no livro Solombra, em que o eu-lírico ceciliano move-se para o mundo do sonho, do sono e da solidão absoluta, e a figura da morte surge como "Medusas da alta noite e espumas breves". A paisagem do lugar se funde com a própria imagem de Cecília no espaço do “jardim arruinado/na desordem decadente?”. O eu expõe as suas indagações diante daquilo que vê, a paisagem que se descortina diante de seus olhos é de ruínas, sombras e morte. Na primeira estrofe, a voz poética evoca a figura de Cecília que é nomeada como um "vulto", ou seja, a imagem não é muito nítida, e isso será complementado nos versos seguintes: "A sua pele morena/a confundir-se/com a sombra", a imagem de um "corpo" que se encontra no espaço da sombra, e também do “olhar de/lustro/perdido no horizonte" está presente em vários poemas de Solombra. O leitor poderá confirmar essa estreita ligação que há entre a imagem de Cecília que é elaborada por Teresa Horta com o sujeito introspectivo desse último livro publicado pela brasileira se fizer uma leitura comparativa entre os dois textos ${ }^{39}$. E a casa que possuía vida e sentido no passado, se encontrava vazia, hostil e desabrigada. As três estrofes que fecham o poema confirmam o espaço arruinado pelo tempo:

\author{
Fiquei diante da casa \\ de seu passado agasalho \\ mas agora tão vazia \\ Mas agora tão fechada \\ tão alheada e sombria \\ hostil desabrigada \\ Na sua melancolia \\ que na dúbia alvenaria \\ mais me parecia assombrada
}

(HORTA, 2009, p. 96).

A concepção de tempo é explorada no sentido de vida no passado e morte no presente. O olhar do sujeito que enxerga o mundo concreto, no caso, a casa feita de "dúbia alvenaria", não vê a mesma imagem por dentro. A palavra "casa" é feita de

\footnotetext{
${ }^{39}$ Duas estrofes retiradas de dois poemas de Solombra poderão ajudar o leitor a confirmar o processo de apropriação e transformação intertextual realizado pela escritora-leitora portuguesa, em relação à poética de Cecília Meireles: "Eu sou essa pessoa a quem o vento chama,/a quem não se recusa a esse final convite,/em máquinas de adeus, sem tentação de volta" (MEIRELES, 2001, p.1273); "Esse rosto na sombra, esse olhar na memória,/o tempo do silêncio, os braços da esperança,/uma rosa indefesa - e esse vento inimigo.” (p.1280).
} 
“dúbia alvenaria", ou seja, por dentro ela representa o lugar habitado no passado pelos vivos e, por fora, se transforma em um espaço fechado, sombrio, desabrigado, vazio e assombrado, que é habitado por mortos. E o sujeito que se encontra do lado de fora da casa revela a impossibilidade de criar um retrato nítido de Cecília, pois esta personagem pertencia ao mundo das sombras, do vago e do fugidio.

Teresa Horta, em sua viagem ao Brasil, é uma viajante que demonstra a sua capacidade de "uma pastora" que, apesar de deixar explícito em seus poemas que é uma prisioneira de sua terra natal, revela com "intensidade" a sua capacidade de "nômadeartista" de registrar os pormenores da viagem feita ao "País das Maravilhas". Vê-se em sua poesia a síntese da experiência de um sujeito que se desloca de seu espaço geográfico, deseja a viagem ao "mundo das nuvens" do vôo, realiza o seu itinerário entre São Paulo e Rio de Janeiro pela Serra do Mar e retorna a seu lugar de origem. E a experiência da viagem proporciona à poeta uma nova visão do Brasil, já que o tema da partida e o processo de composição dos Poemas do Brasil são matérias dos quatro poemas que encerram o livro: "Partida", "Mala dos livros", "Memórias do Brasil" e "Amigas brasileiras".

A viagem irá possibilitar à escritora elaborar uma imagem do Brasil diferente daquela encontrada no papel, a estabelecer novos laços de amizade com as "mulheres brasileiras" e com os críticos brasileiros e estudiosos de sua obra. O livro revela o "canto" de um pássaro que migra para as terras exóticas do Brasil, em busca de um novo tom para a sua poesia cantante. Assim, pode-se afirmar que a poeta portuguesa é uma espécie de viajante:

tocado pela graça põe seu corpo à disposição do inefável e do indizível que, metamorfoseados em impulsos e emoções, se transformam em sentido e resultam em palavras e imagens, ícones, desenhos, cores, traços - em rastro que transfigura a efervescência de uma experiência em incandescência expressiva. (ONFRAY, 2009, p. $62-63)$.

Nos "rastos" da letra a poeta registra, através da técnica da escrita, esse conjunto de poemas que expressam uma "geografia sentimental" sobre a viagem feita ao Brasil, em 2007. E, se essa escritora assume o papel de seres mágicos e imaginários que voam entre Brasil e Portugal, os seus poemas não são diferentes, porque são inerentes a esses seres voadores. No poema "Rasto", o leitor irá encontrar a imagem do sujeito lírico que 
escreve e assume a identidade dos seres sobrenaturais. O processo metalinguístico está presente em vários poemas, em que o sujeito poético aponta a "palavra" como um ser sobrenatural. Veja-se, a seguir, fragmento do poema "Rasto":

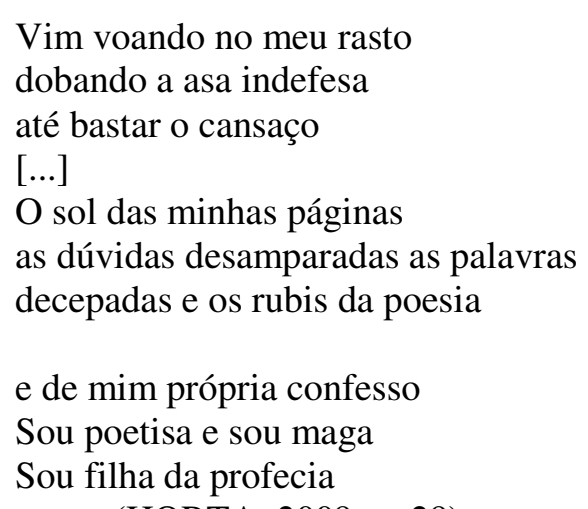

(HORTA, 2009, p. 29).

Essa poesia retornará ao Brasil em setembro de 2009, em mais uma viagem realizada por Maria Teresa Horta para participar do XIII Seminário Nacional e IV Seminário Internacional Mulher e Literatura - Memórias, Representações, trajetórias, na UFRN (Natal - RN), como uma das homenageadas do Congresso. É importante destacar que durante o evento ocorreu o lançamento dos Poemas do Brasil, quando então puderam alçar novos voos.

Este texto também foi motivado por uma experiência de viagem, pois em setembro do mesmo ano fui a Natal para participar do referido congresso. E foi durante o evento que eu pude conhecer Maria Teresa Horta e descobrir seus Poemas do Brasil, lidos por mim, pela primeira vez, no momento em que ainda me encontrava deslocada do meu próprio espaço geográfico. Este texto, de alguma maneira, revela alguns aspectos das técnicas que utilizei a partir da minha experiência de viajante, pois quando eu retornei ao meu lugar de origem trouxe o livro de poemas, o risco da letra no autógrafo, um cartão de visitas e as fotografias tiradas em alguns momentos do evento, principalmente durante a conferência de abertura e no lançamento do livro. Enfim, o que ficou da viagem que realizei ao norte do País não foram as belezas do belo lugar que era desconhecido para mim, mas o encontro com essa poesia sobre o Brasil e com a 
sua autora. E conhecer a poeta-viajante Maria Teresa Horta foi o que mais impulsionou a confecção deste artigo, aqui exposto como parte de uma experiência de viagem.

\section{REFERÊNCIAS}

ANDRADE, O de. Pau-brasil. 2.ed. São Paulo: Globo, 2003.

CARROLL, L. As aventuras de Alice no País das Maravilhas; Através do espelho e o que Alice encontrou por lá. Ilustrações originais de John Tenniel. Tradução de Maria Luiza X. de A. Borges. Rio de Janeiro: Zahar, 2009.

DOMingues, A. M. Prefácio. In: HORTA, M. T. Poemas do Brasil. São Paulo: Brasiliense, 2009. p.11-14.

HORTA, M. T. Poemas do Brasil. São Paulo: Brasiliense, 2009.

MEIRELES, C. Cecília Meireles: crônicas de viagens 2 (1953). Apresentação e planejamento editorial de Leodegário A. de Azevedo Filho. Rio de Janeiro: Nova Fronteira, 1999. p.101-104. . Solombra. In: . Poesia completa. Rio de Janeiro: Nova Fronteira, 2001. 2001a. Poesia completa. Rio de Janeiro: Nova Fronteira,

ONFRAY, M. Teoria da viagem: poética da geografia. Tradução de Paulo Neves. Porto Alegre: L\&PM Editores, 2009.

SANCHEZ NETO, M.. Cecília Meireles e o tempo inteiriço. In: MEIRELES, C. Poesia completa. Rio de Janeiro: Nova Fronteira, 2001. p.xxi-lix.

Artigo recebido em 30/04/2011 Aceito para publicação em 02/08/2011 